\title{
PROSEDUR WAREHOUSING DALAM PENANGANAN BARANG DI GUDANG PT. RITRA CARGO INDONESIA CABANG SEMARANG
}

\author{
Sulida Erliyana ${ }^{1}$, Hermanus Panana Bao ${ }^{1}$ \\ ${ }^{1}$ Program Studi KPN Politeknik Bumi Akpelni \\ Jl. Pawiyatan Luhur II/17, Bendan Dhuwur, Semarang. \\ Email: erliyanasulida@yahoo.co.id
}

\begin{abstract}
Abstrak
Tujuan dari penulisan ini adalah untuk mengetahui bagaimana prosedur warehouse, serta mengetahui tugas operasional keagenan dan mengetahui hambatan-hambatan dalam penanganan barang digudang. Metode pengumpulan data yang didapat dalam penyusunan ini diambil melalui observasi, interview dan kepustakaan sebagai dasar analisa kualitatif dan pemecahan masalah yang telah dikemukakan oleh penulis. Berdasarkan hasil pembahasan yang telah dibuat maka dapat diketahui bahwa perusahaan PT.Ritra Cargo Indonesia mempunyai kegiatan terhadap penanganan barang di gudang yang terdiri dari proses peneriman, penyimpanan dan pengiriman. Dari hal tersebut dapat di simpulkan bahwa PT..Ritra Cargo Indonesia dalam menjalankan kegiatan penanganan barang digudang, masih adanya hambatan tapi perusahaan dapat mengatasi dengan cara peningkatan pemeliharaan, menjalin hubungan dan komunikasi yang baik dengan pihak instasi terkait guna memperlancar segala kegiatan.
\end{abstract}

Kata Kunci : Penanganan, Barang, Gudang

\section{PENDAHULUAN}

Sejalan dengan pelaksanan pembangunan di Indonesia yang sasaran utamanya di bidang pembangunan ekonomi, maka kegiatan perdagangan merupakan salah satu sektor pembangunan ekonomi, senantiasa ditumbuh kembangkan peranannya. Untuk memperlancar arus barang dan jasa guna menunjang kegiatan perdagangan tersebut, diperlukan adanya sarana pengangkutan yang memadai, baik pengangkutan melalui darat, laut maupun udara.Undang- Undang No.17 Tahun 2008 Tentang Pelayaran menjadi suatu sarana yang sangat strategis dalam terwujudnya wawasan nasional serta menjadi sarana vital yang menunjang tujuan persatuan dan kesatuan nasional.

Sesuai dengan amanat diatas, menunjukkan bahwa pelaksanaan pembangunan di sektor transportasi laut antara lain diarahkan untuk meningkatkan kegiatan perdagangan antar pulau (inter insuler), disamping perdagangan antar Negara (impor-ekspor). Adanya peningkatan arus barang dan jasa melalui kegiatan perdagangan melalui laut tersebut, maka keberadaan perusahaan jasa pengangkutan laut maupun perusahaan jasa yang memiliki keterkaitan, kaitannya dengan kegiatan pengangkutan melalui laut, seperti Perusahaan Ekspedisi Muatan Kapal Laut (EMKL) maupun Perusahaaan LOGISTIK memiliki peranan yang sangat besar.

Dengan undang-undang No.17 tahun 2008 tentang pelayaran termasuk keagenan, bongkar muat dan pergudangan harus dilaksanakan oleh sebuah perusahaan pelayaran. Perkembangan peraturan pemerintah selanjutnya mengharuskan kegiatan bongkar muat dilakukan oleh perusahaan yang berdomisili di daerah masing-masing. Hingga kemudian mulai didirikan perusahaan-perusahaan Logistik diberbagai daerah di Indonesia termasuk PT.RitraCargoIndonea

PT. Ritra Cargo Indonesia, Semarang merupakan salah satu kantor Cabang Semarang sedangkan kantor pusatnya sendiri berada di Jakarta, selain disemarang PT. Ritra Cargo Indonesia juga memilki beberapa kantor cabang di kota kota besar di Indonesia lainnya. Ritra logistik merupakan perusahaan yang bergerak di bidang pengiriman barang baik darat, laut maupun udara domestik maupun internasional. PT. Ritra Cargo Indonesia selain melayani pengiriman darat laut dan udara juga 
melayani manajemen proyek, warehouse logistic dan distribusi

Berdasarkan latar belakang yang telah diuraiakan diatas, maka penulis selanjutnya mengidentifikasi masalah dalam penelitian ini sebagai berikut :

1) Prosedur warehousing dalam penanganan barang digudang

2) Dokumen-dokumen yang diperlukan dalam penanganan barang digudang

3) Pihak-pihak yang terlibat dalam dalam penanganan barang digudang

4) Masalah dan kendala yang menghambat dalam penanganan barang digudang

\section{LANDASAN TEORI}

Menurut Rudi M.Tambunan (2013) mendefenisikan prosedur sebagai pedoman yang berisi prosedur operasional yang ada di dalam suatu organisasi yang digunakan untuk memastikan bahwa semua keputusan dan tindakan, serta penggunaan fasilitasfasilitas proses yang dilakukan oleh orangorang dalam organisasi yang merupakan anggota organisasi berjalan efektif dan efisien ,konsisten ,standard an sitematis.

Menurut Juan Kasma (2012) menyatakan bahwa prosedur adalah suatu standar atau pedoman tertulis yang dipergunakan untuk mendorong dan menggerakan suatu kelompok untuk mencapai tujuan organisasi.

Dari pengertian diatas dapat disimpulkan bahwa prosedur adalah suatu urutan yang tersusun biasanya melibatkan beberapa orang dalam satu bagan departemen atau lebih, serta disusun untuk menjamin penanganan secara lebih seragam transaksi perusahaan yang terjadi berulang-ulang.

Menurut Elok Widiyati dan Ridwan (2014) warehouse adalah gudang atau bangunan untuk menyimpan barang dalam waktu lama dimana pengaturan barang dibuat sedemikian rupa sehingga memudahkan, penerimaan,penyusunan,pera watan ,penerimaan

Menurut Hananto Soewendo (2015) gudang adalah suatu ruangan tertutup dengan dinding dan atap yang hanya dapat dimasuki melalui pintu untuk menyimpan atau menimbun barang-barang dagangan.

Menurut Lucas dan Rumsari (2004) warehousing atau Pergudangan merupakan serangkaian kegiatan pengurusan dalam penyimpanan logistik mulai dari kegiatan penerimaan, pencatatan, pemasukan, penyimpanan, pengaturan, pembukuan, pemeliharaan, pengeluaran dan pendistribusian samapai dengan kegiatan pertanggungjawaban pengelolaan gudang (pembuatan laporan laporan) dengan tujuan mendukung kontinuitas kerja unit kerja, sekaligus mendukung efektivitas dan efisiensi organisasi secara keseluruhan.

Menurut Warman (2004) warehousing atau Pergudangan adalah sebuah bagian dalam sebuah sistem logistik perusahaan yang berfungsi untuk menyimpan produk - produk perusahaan (baik itu bahan baku, part produk, produk dalam proses, ataupun produk jadi) pada dan diantara titik asal produk (produsen) dan pada titik konsumsi (konsumen), serta menyediakan informasi bagi manajemen mengenai status, kondisi, serta arus/perpindahan produk yang disimpan dalam gudang

Dari pengertian diatas dapat disimpulkan bahwa kegiatan penggudangan tidak sekedar kegiatan memasukkan barang dalam ruang penyimpanan (gudang), tetapi lebih dari itu, dalam kegiatan penggudangan penting dilakukan perencanaan, pengorganisasian, serta pengendalian logistik sehingga kegiatan tersebut dapat menjamin dan menjaga kelangsungan dan kesinambungan setiap aktivitas dalam setiap unit kerja di dalam suatu organisasi.

\section{METODE}

Metodologi yang digunakan dalam penelitian ini adalah dengan cara :

1. Metode Interview ( wawancara)

Penulis memperoleh data dengan mengadakan Tanya jawab dengan narasumber dan pihak-pihak terkait yang berhubungan dengan masalah, diantarannya staf pergudangan dan pembimbing di PT.Ritra Cargo Indonesia 
2. Metode Observasi (pengamatan)

Penulis memperoleh informasi dengan cara mengadakan pengamatan ssecara langsung di lapangan untuk mencari penyesuaian dari keterangan yang diperoleh dengan keadaan sebenarnya dilapangan .dalam hal ini pengamatan pada kegiatan warehousing di PT.Ritra Cargo Indonesia

3. Metode Studi ustaka

Metode studi pustaka yaitu metode pengumpulan data yang datanya diperoleh dari membaca dan mempelajari buku atau referensi yang berkaitan dengan maslalah yang akan dibahas

4. Analisis data yang digunakan adalah analisis Kualitatif

\section{HASIL DAN PEMBAHASAN \\ Prosedur Warehousing Dalam \\ Penanganan Barang di Gudang PT \\ Ritra Cargo Indonesia}

Dalam prosedur

penangangan barang melalui bebarapa tahapan yang dapat penulis jelaskan sebagai berikut:

\section{a. Penerimaan}

Penerimaan barang adalah merupakan segala awal arus barang yang bergerak di gudang. Penerimaan barang dari pemasok atau penyedia barang memang kelihatan mudah, namun bila hal ini tidak memiliki sistem yang mengatur, maka bisa dipastikan akan mengganggu produktifitas alur barang. Penerimaan barang harus dilakukan secara cermat karena merupakan perpindahan tanggung jawab dari penyedia kepada pengguna melalui jasa transportasi. Untuk menghindari terjadinya kesalahpahaman dalam penerimaan barang maka perlu dibuat mekanisme yang tepat dan didukung oleh administrasi yang benar. kegiatan penerimaan barang meliputi Pemeriksaan barang yang bertujuan untuk memastikan apakah barang yg diterima sudah sesuai dengan kontrak pengadaan barang, baik jumlah, jenis, kondisi, maupun harganya; memastikan apakah jumlah persediaan yang diterima telah dicatat pada arsip data inventaris/catatan persediaan; pemisahan dan pembetulan ketidaksesuaian dalam pencatatan kualitas barang berdasarkan barang yang ada.

Pemeriksaan barang yang dilakukan meliputi: pemeriksaan fisik (Jenis, tipe, kualitas, jumlah, kondisi barang, kemasan); pemeriksaan dokumen (kelengkapan dan kesesuaian dokumen, uraian barang, jumlah, harga, waktu pengiriman)

\section{b. Penyimpanan}

Penyimpanan barang adalah menempatkan barang di dalam gudang untuk disimpan atau dipersiapkan untuk proses selanjutnya. Penyimpanan barang dilakukan sesuai dengan karakteristik barang. Penyimpanan barang sebagai persyaratan dalam penyimpanan barang adalah persediaan mudah ditemukan, sederhana dan efisien, aman, persediaan lama dapat dikeluarkan lebih dahulu dan persediaan yang mendekati expired dikeluarkan terlebih dahulu (azas FIFO dan FEFO) Penyimpanan barang yg efektif membutuhkan kerapihan, disipilin dan cara yang sesuai.

Aktivitas penyimpanan barang merupakan kegiatan penentuan jumlah unit per kelompok; untuk barang kecil dikelompokkan per bungkus dengan kuantitas tertentu, pemberian identitas barang. Penyimpanan dapat dilakukan di tempat yang sesuai secara sistematis, penyimpanan berdasarkan prinsip FIFO memudahkan dalam pemeriksaan kembali untuk barang yang telah disimpan dalam masa tertentu. buatkan layout penyimpanan barang (Lay out Gudang), jika jenis barang banyak, dalam daftar inventory/barang tuliskan lokasi penyimpanan barang.

Identitas barang berisi informasi tentang nama barang, kode barang; spesifikasi barang, satuan barang, jumlah barang, tanggal penerimaan barang, nama penyedia barang dan lain-lain (sesuai kebutuhan). Proses penyimpanan barang direncanakan penempatan barang-barang dengan frekuensi keluar masuk tinggi di lokasi yg mudah dijangkau, misalnya bagian tengah 
fallet, lantai dasar; menggunakan sistem kode lokasi penyimpanan; penandaan daerah penyimpanan untuk barangbarang berukuran besar dan berat, serta mempelajari kemungkinan mengatur ukuran lot bagi barang yg dikirim atau sistem pengemasan barang.

Pengendalian persediaan meliputi beberapa kegiatan antara lain pemeliharaan bukti dokumentasi yang akurat mengenai penerimaan, penyimpanan dan pengiriman dari suatu pergudangan, dan penggunaan informasi yang dapat diambil dari catatancatatan tersebut. Kartu barang persediaan merupakan alat pengendalian persediaan yang paling penting sehingga harus menyediakan informasi yang mutakhir mengenai kuantitas persediaan dan lokasi dari semua barang yang disimpan di gudang tersebut.

Informasi pada kartu catatan persediaan meliputi: nomor referensi, uraian barang, klasifikasi persediaan barang, lokasi/tempat penyimpanan barang, perincian mengenai jumlah persediaan barang. Pemeriksaan persediaan barang diperlukan untuk memeriksa kebenaran catatan persediaan, menetapkan nilai persediaan, mendeteksi adanya kehilangan dan bisa digunakan sebagai bahan penilaian staf gudang.

\section{c. Pengiriman/Pendistribusian}

Pengiriman barang adalah mempersiapkan pengiriman fisik barang dari gudang ketempat tujuan yang disesuaikan dengan dokumen pemesanan dan pengiriman serta dalam kondisi yang sesuai dengan persyaratan penanganan barangnya. Sebelum melakukan pengiriman barang ke tempat tujuan aktifitas yang dilakukan setelah barang disiapkan adalah memastikan kembali barang yang disiapkan sama atau sesuai dengan dokumen pengambilan barang yang sudah di kirimkan sebelumnnya mengantisipasi hal tersebut pihak gudang sudah menyiapkan barcode untuk mendata barang yang akan keluar secara satupersatu sesuai kode barang yang sudah tertempel pada kemasan atau fisik barang pengepakan (pack) dan pemilahan (sortasi). Pengepakan yang dilakukan secara sendiri-sendiri atau digabungkan untuk kenyamanan/keamanan barang. Sedangkan sortasi adalah mengumpulkan pengepakan ke tujuan yang benar dan harus membandingkan antara kapasitas muatan dan tujuan yang akan dilalui. Penerimaan, Penyaluran, Penyimpanan dan Pendistribusian Barang Yang terpenting dilakukan dalam hal pengepakan dan pemilahan barang adalah adanya alamat tujuan pengiriman barang, mengurangi waktu pencarian dalam pengepakan, pengelompokan barang yang akan dikirim, pemberian label atau tanda khusus untuk pengepakan, menghitung jumlah peti/koli, dan mengelompokan pengepakan ke dalam alur pengiriman pengecekan fisik, tipe, jumlah dan kondisi barang, perlindungan dan pengemasan barang dan pemuatan barang untuk diangkut ke tempat tujuan

\section{Dokumen Yang Dibutuhkan Dalam Penanganan Barang di Gudang}

Dokumen administrasi gudang dianggap sangat penting oleh perusahaan karena dokumen tersebut bertujuan untuk dibukukan pada setiap kegiatan-kegiatan yang dilakukan oleh bagian. dokumen tersebut harus dikelola sebaik mungkin. Pengelolaan administrasi gudang meliputi kegiatan bagian gudang dalam proses Penerimaan, Penyimpanan dan Pengiriman barang haruslah dilengkapi dokumen dokumen pendukung sebagi hasil dari laporan kegiatan dan sebagi tanda bukti penerimaan, penyimpanan, dan pengiriman barang yang dilakukan oleh manajen gudang. Adapun dokumen dokumen yang dibutuhkan dalam kegaiatan penerimaan, Penyimpanan dan pengiriman adalah sebagai berikut :
a. Delivery Order
b. Surat Jalan
c. Receiving Form
d. Layout
e. Delivery from
f. Goods Receive Advice
g. Tally Sheet 


\section{Pihak-Pihak yang Terkait Dalam Penanganan Barang di Gudang PT.Ritra Cargo Indonesia \\ a. Eksportir/Seller \\ b. Freight Forwading / Perusahaan Jasa Pengiriman \\ c. Importir/Buyer \\ d. Perusahaan Angkutan Barang \\ e. Surveyor \\ f. Maskapai Asuransi}

\section{Hambatan Yang Dihadapi dan Solusinya :}

a. Terjadinya Keterlambatan Dokumen Barang Kepada Pihak Gudang saat barang akan masuk kegudang, hal ini dapat diatasi dengan Lebih mempererat lagi komunikasi dengan pihak pemilik barang sehingga pada saat proses penerimaan ,penyimpanan maupun pengiriman tidak terhambat dan mengalami kendala karena akan menghambat proses operasional digudang terlebih mengenai dokumen barang digudang

b. Kerusakan barang akibat terlalu lama, perlu disiasati dengan perhatian dan pemeliharaan terus ditingkatkan dan selalu diperhatikan untuk mengurangi resiko kerusakan pada kemasan maupun barang yang ada digudang

c. Keterlambatan dokumen pengiriman barang kepada pihak gudang saat barang akan dikeluarkan, perlu adanya koordinasi dan kerjasama perusahaan PT.Ritra Cargo Indonesia cabang Semarang dengan perusahaan lain sebaiknya lebih di pererat lagi. Untuk mendapatkan kepercayaan yang lebih baik lagi dan juga untuk lebih memajukan perusahaan menjadi lebih baik

\section{KESIMPULAN}

1. Kegiatan Warehousing digudang terdiri dari 3 proses yaitu

a. Penerimaan proses awal digudang yaitu dilakukan proses pengecekan barang dan dokumen selanjutnya barang akan disimpan dalam gudang sesuai dengan karakteristik barang.

b. Penyimpanan barang adalah menempatkan barang di dalam gudang untuk disimpan atau dipersiapkan untuk proses selanjutnya

c. Pengiriman merupakan proses mempersiapkan pengiriman fisik barang dari gudang ketempat tujuan sesuai alamat yang tertera di dalam delivery order tersebut

2. Dokumen yang dibutuhkan dalam penanganan barang digudang :

a. Delivery Order

b. Surat Jalan

c. Receiving Form

d. Layout

e. Delivery from

f. Goods Receive Advice

g. Tally Sheet

3. Pihak - pihak yang terkait dalam penanganan barang di gudang PT.Ritra Cargo Indonesia :

a. Eksportir/Seller

b. Freight Forwading /Perusahaan Jasa Pengiriman

c. Importir/ Buyer

d. Perusahaan Jasa Angkutan

e. Maskapai Asuransi

f. Surveyor

4. Hambatan yang dihadapi dan solusinya:

a. Terjadinya Keterlambatan Dokumen Barang Kepada Pihak Gudang saat barang akan masuk kegudang, hal ini dapat diatasi dengan Lebih mempererat lagi komunikasi dengan pihak pemilik barang sehingga pada saat proses penerimaan, penyimpanan maupun pengiriman tidak terhambat dan mengalami kendala karena akan menghambat proses operasional digudang terlebih mengenai dokumen barang digudang

b. Kerusakan barang akibat terlalu lama, perlu disiasati dengan perhatian danpemeliharaan terus ditingkatkan dan selalu diperhatikan untuk mengurangi 
resiko kerusakan pada kemasan maupun barang yang ada digudang

c. Keterlambatan dokumen pengiriman barang kepada pihak gudang saat barang akan dikeluarkan, perlu adanya koordinasi dan kerjasama perusahaan PT.Ritra Cargo Indonesia cabang Semarang dengan perusahaan lain sebaiknya lebih di pererat lagi. Untuk mendapatkan kepercayaan yang lebih baik lagi dan juga untuk lebih memajukan perusahaan menjadi lebih baik.

\section{DAFTAR PUSTAKA}

Dwiantara Lucas,Rumsari Hadi, 2004, Manageman Logistik. PT.Gramedia Widiasarana Indonesia, Jakarta.

Kasma,Juan, 2012, Standar Operating Procedure Perpajakan Perusahaan Jasa, Alfabeta, Bandung.
Putri Rizka, 2005, Optimalisasi Penanganan Muatan Cargo Kaca Di KM.Hanglima Oleh PT. Sarana Bandar Nasional

Ria Kusuma Handayani, 2004, Perancangan Sistem Informasi Pengiriman Barang Pada PT.Ritra Cargo Indonesia

Soewendo,Hananto, 2015, Penanganan Muatan Kapal di Pelabuhan dan Peralatannya, Maritim Jangkar, Jakarta.

Tambunan,Rudi.M., 2013, Pedoman Penyusunan Standard Operating Procedures, Malestas Publishing, Jakarta.

Warman,Jhon, 2004, Manajemen Pergudangan, Pustaka Sinar harapan, Jakarta.

Widyawati, Elok dan Ridwan, 2014, kamus kepelabuhan dan pelayaran, Leutikaprio, Yogyakarta. 